\title{
Explorations of Improvements in Vocational Guidance Course for College Students Driven by Innovation and Entrepreneurship Education
}

\author{
Jiang Yanhong \\ School of Environmental Science and Engineering, Xiamen University of Technology, Xiamen, China
}

Keywords: innovation and entrepreneurship education; vocational guidance course; employment of college students

\begin{abstract}
In the new round of entrepreneurship boom raised by innovative-oriented countries, vocational guidance in colleges and universities shall take the opportunity to implement the vocational guidance idea of "employment increasing by entrepreneurship", and promotes the innovation and entrepreneurship education to become the internal force of employment of college students. This paper re-understands the significance of innovation and entrepreneurship education in vocational guidance for college students, takes the initiative to find out deficiencies, to integrate the both, and gives full play to the promotion of innovation and entrepreneurship education in vocational guidance course for college students.
\end{abstract}

\section{Introduction}

At present, under the new-type innovative national strategy of "mass entrepreneurship and innovation", the innovation and entrepreneurship education concept of "employment increasing by entrepreneurship" puts forward new requirements and new path for vocational guidance for college students, and also raises new exploration on the development of vocational guidance course for college students.

Premier Li Keqiang proposed to stimulate the entrepreneurial spirit and innovative genes of the nation. As the backbone of the national talent training, colleges and universities should stand on the new starting point of strengthening innovation and entrepreneurship education to promote the reform and development of higher education, and integrate innovation and entrepreneurship education into professional education and in the vocational guidance for college students. Colleges and universities shall focus on the characteristics of innovation and entrepreneurship education in social development, widen the connotation of vocational guidance, improve the employment quality, actively explore the integration of the both and the promotion of innovation and entrepreneurship education in vocational guidance course for college students.

From the staring of innovation and entrepreneurship education in colleges and universities by Tsinghua University Business Plan Competition, to the spreading of innovation and entrepreneurship education is in colleges and universities across the country, these explorations have trained many excellent talents for the development of innovative country, and promoted the innovative development of science and technology and society. However, the top-down policy from the country is insufficient. It is necessary to look forward the continuous development of innovation and entrepreneurship education with a long-term vision, make full use of development innovation of course guidance of colleges and universities, mobilize the more in-depth innovative force of college students, and actively explore the significance of innovation and entrepreneurship education in vocational guidance for college students.

\section{The Significance of Innovation and Entrepreneurship Education in Vocational Guidance for College Students}

Innovation and entrepreneurship education is to cultivate innovative talents with innovative idea and basic quality of entrepreneurship to meet social demands in new trend. Colleges and universities shall adapt to the requirements of new times and demand of youth growth, train 
innovative awareness, entrepreneurship capability and competence of college students, enhance innovative and entrepreneurial concept and skills, so as to inspire innovation and entrepreneurship potential of college students, widen channels of vocational development, understand national policy on innovation and entrepreneurship and achieve high-quality employment.

\subsection{To inspire innovative genes}

Throughout history, it can be easily found that every great invention and creation comes from innovation. The Chinese nation has never lacked the genes of innovation. From the four great inventions to the present quantum technology, the creativity of the Chinese nation is reflected. Youth is the future of the country. Higher education should attach importance to innovation and entrepreneurship education, and cultivate students' interest and fun in actively innovating and creating, thus, inspiring college students' innovative genes as the driving force behind college students' innovation and entrepreneurship. Vocational guidance courses should pay attention to the cultivation of college students' awareness of innovation and entrepreneurship, so that the curriculum is closer to the requirements of the new era, to not only encourages college students to innovate boldly, but also help their studies and provide more possibilities for future employment of college students.

\subsection{To widen channels of vocational development}

"Innovation Entrepreneurship" effectively widens the traditional concept of the workplace. Employment is not only to be engaged in corresponding positions in enterprises and institutions, but also to start their own business, to create their own workplace, to transform innovation and entrepreneurship into the value benefiting the society, and to make the path of college students' career development more diversified and personalized. Therefore, innovation and entrepreneurship education must be integrated through the whole process of the development of college students' academic development, and into the vocational guidance course system, to become the complementary part, and to give full play the combined force of innovation and entrepreneurship education and professional education in the talent training of colleges and universities through the career guidance.

\subsection{To promote the employment of college students}

According to the data of the China College Student Employment Report, the proportion of college graduates who started their business after graduation in China has almost doubled from 1.6\% in 2011 to 3.0\% in 2017. Innovation and entrepreneurship are becoming a new career development path, attracting more young people. Vocational guidance should be based on the needs of college students' vocational development, incorporating innovation and entrepreneurship education in the curriculum, and responding to the new trend of adapting to the concept of employment and entrepreneurship. Entrepreneurship of college students can not only accelerate the transformation of innovation achievements, but also achieve scientific and technological innovation; it can also provide more jobs for the society, solve people's livelihood problems, and ensure social stability. Therefore, to increase college students' innovation and entrepreneurship education is the only way to implement the spirit of the 19th National Congress, update the vocational guidance curriculum system, and strengthen the vocational guidance of college students.

\section{The Current Status of Innovation and Entrepreneurship Education in Vocational Guidance for College Students}

Innovation entrepreneurship education has made many positive attempts in colleges and universities, and has achieved many satisfying achievements. However, in vocational guidance courses, there still are a certain degree of deficiencies in the status quo of innovation and entrepreneurship education. 


\subsection{The lose combination with innovation and entrepreneurship education}

At present, colleges and universities attach great importance to innovation and entrepreneurship, and have established institutions such as college student innovation and entrepreneurship parks, innovation and entrepreneurship colleges, etc., in order to carry out more targeted innovation and entrepreneurship education for college students. However, the career guidance course is offered at the employment guidance center under the student affairs office, the preliminary course of entrepreneurship is undertaken by the innovation and entrepreneurship park under the academic affairs office, the innovation and entrepreneurship education and the vocational guidance of college students belong to different management departments, and there is a certain vacuum in the management institutions and curriculum construction. The gap between management functions hinders the integration of innovation and entrepreneurship education and vocational guidance. Therefore, coordinating their respective functions in college students' innovation and entrepreneurship has become a major problem. It is difficult to implement the innovation and entrepreneurship education of college students, and it is difficult to give play to the role of innovation and entrepreneurship education in vocational guidance for college students.

\subsection{The lack of innovation and entrepreneurship contents}

Vocational guidance course has been incorporated into public compulsory courses in most colleges and universities and are offered by the career guidance center. The vocational guidance courses mainly include modules such as vocational career, career orientation, career ability, interview skills, employment policy, and employment psychology, which will greatly help college students' job hunting and employment, but the content of innovation and entrepreneurship is less, and the cultivation of innovative thinking and the training of entrepreneurship ability are relatively lacking, and the study of innovation and entrepreneurship mostly takes the simple form of lecture. The curriculum did not update the curriculum modules in a timely manner according to the changes in the new situation of social employment and the needs of college students for innovation and entrepreneurship, and the content of innovation and entrepreneurship education in the vocational guidance curriculum system is insufficient.

\subsection{The insufficient teaching staff}

Vocational guidance courses are held mainly by ideological and political staff in most colleges and universities. Course teachers are mostly part-time teachers, and the time and effort invested cannot guarantee the in-depth exploration of the course. Moreover, the professional structure and professional foundation of the teaching staff are relatively not solid, lacking vocational guidance and professional knowledge background related to innovation and entrepreneurship, and the theoretical basis of innovation and entrepreneurship is insufficient. The construction and development of the vocational guidance curriculum system lacks the cultivation of academic leaders and professional teams. The teachers are mainly young counselors and teachers who just graduated from the school, with relative lack of practical experience, which has affected the effectiveness of innovation and entrepreneurship education in vocational guidance curriculum.

\subsection{The lack of practicableness}

At present, the teaching methods of vocational guidance course in colleges and universities mainly are traditional infusion teaching such as classroom teaching and lecture exchange. The teaching methods of innovation and entrepreneurship education in vocational guidance course also tend to be classroom teaching, staying in the teaching of entrepreneurship policy, innovation and entrepreneurship case analysis, which cannot adapt to the diverse thinking changes of college students, lacking the corresponding training to the course, which is difficult to mobilize the innovative thinking of college students and stimulate entrepreneurial awareness. In the course guidance, the main focus is from the perspective of entrepreneurship, ignoring the training and development of innovative entrepreneurship thinking. The teaching model lacks a variety of innovative entrepreneurial practice activities to enrich the innovation and entrepreneurial experience 
of college students, and lacks the teaching methods to enhance the level of innovation and entrepreneurship practice.

\section{The Exploration of Innovation and Entrepreneurship Education in Vocational Guidance Course for College Students}

Carrying out innovation and entrepreneurship education has a positive effect on the development of vocational guidance courses for college students. The improvement of curriculum can be reflected in the optimization and improvement of curriculum management, the construction of teaching staff, the deepening of curriculum guidance practice, and the deepening of the integration of industry and education, which is a booster that guides the development of the course.

\subsection{To optimize curriculum management}

Colleges and universities should focus on integrating the advantages of employment guidance centers, innovation and entrepreneurship parks in college students' innovation and entrepreneurship education, and highlight the role of the two in the career guidance of college students. In the management of vocational guidance course, innovation and entrepreneurship education is taken as a breakthrough to implement comprehensive reform of higher education, deepen the connotation of curriculum management, and improve the popularity of innovation and entrepreneurship education among college students in terms of personnel training programs, curriculum system construction and teaching resources guarantee. For example, to establish career guidance courses for students in science and engineering, liberal arts, engineering, management, arts, and other disciplines. Incorporating college students' innovation and entrepreneurship education in professional training and discipline construction, to provide teaching software and hardware support, curriculum construction, professional training and other rich curriculum development convenience for the stimulation of college students' innovative genes and the cultivation of entrepreneurial consciousness.

In the management service, the academic affairs office is responsible for coordinating the role of professional guidance courses of various disciplines. Different departments work together to provide innovative and entrepreneurial guidance services for college students, and the innovation and entrepreneurship education is integrated through the whole process of professional talent training in various disciplines. The innovation and entrepreneurship parks provide free office space for college students' entrepreneurial projects, and provide practical assistance for entrepreneurial policies such as registering companies, patent applications, laws and regulations, and play the role of a business incubator. The employment guidance center teaches and trains college students on innovative entrepreneurial thinking and ability development. In the professional study, it is necessary to cultivate the innovative spirit, entrepreneurial awareness, entrepreneurial skills and entrepreneurial spirit of college students, and lead them into the innovation and entrepreneurship to practice their own ideas on innovation and entrepreneurship.

\subsection{To promote the curriculum improvement}

Many colleges and universities have established entrepreneurship basic courses to strengthen innovation and entrepreneurship education, but the content of innovative education is easily overlooked. Innovation is the foundation of entrepreneurship, innovation training is the premise of high-quality employment for college students, and it is also the internal motivation for college students to actively start businesses. The career guidance course should apply the innovation and entrepreneurship education to the construction and improvement of the vocational guidance course system for college students, and promote innovation and entrepreneurship education as part of the employment guidance and career curriculum modules. In the original curriculum system, career clover and balance wheel career guidance tools are applied to combine with innovative thinking entrepreneurship training, guide students to think about the feasibility, innovation and operability of career, give full play to its own characteristics and advantages, analyze the workplace environment, and let the career guidance courses serve the workplace needs of college students for innovation and 
entrepreneurship. In innovative training method, the theory and tools of innovative thinking training are applied to enlighten the innovative thinking of college students and carry out the training of innovation and entrepreneurship awareness, integrate career guidance, college career planning, academic planning, innovation and entrepreneurship education into the vocational guidance course of college students, and construct the vocational guidance curriculum system for college students of "innovation and entrepreneurship + career guidance".

\subsection{To strengthen the curriculum teaching staff}

Colleges and universities should build a faculty team for the vocational guidance course for college students through "introducing from outside and cultivating inside", increase investment through the recruitment of talents, and introduce experienced professional guidance talents and curriculum teachers with innovative entrepreneurship education and practice to improve the teaching staff of vocational guidance courses. It is necessary to strengthen the training of teachers in the existing vocational guidance courses of various majors, and provide opportunities for further study such as practical training and learning training. In combination with the requirements of vocational guidance course, the young teachers with higher comprehensive quality, vocational guidance experience, and the theoretical knowledge of education, management, psychology and career, who are willing to undertake the vocational guidance course for college students are selected in colleges and universities. It is necessary to give them the opportunity to learn and improve the vocational guidance ability, and encourage them to take the examination of professional qualification certificates, such as professional instructors, career planners, innovative engineers, college entrepreneurial instructors and other professional qualifications, to improve the professional literacy and ability level of teaching course of young teachers in the vocational guidance course.

Employing external tutors to attract professional talents of social institutions and organizations such as industry experts and human resources directors who are experienced in career guidance and innovation and entrepreneurship to join the teaching team of college students' career guidance and innovation and entrepreneurship, through various forms like "enterprise tutor entering the campus" and "industrial experts face-to-face". It is necessary to create a team of vocational guidance courses with innovative entrepreneurial knowledge and skills, and enrich the teacher structure of the curriculum team, establish a "double-capability" teaching staff for vocational guidance of college students, set up curriculum group, give full play to the professional guidance of teachers and external mentors, and refine the contents of different modules of vocational guidance courses, and let enterprise instructors bring the new trends of industry innovation and entrepreneurship to the whole process of curriculum construction and vocational guidance.

\subsection{To expand guidance content}

The vocational guidance is to provide counseling, guidance and assistance to job seekers for employment, employment stability, career development and the rational use of employers. ${ }^{(1)}$ Its main role is to help the employment of college students, promote employment stability, and achieve career development. Innovation and entrepreneurship education points out a new career model for college students' career development and employment, establishes the foundation of college students' entrepreneurship with unique scientific technological innovation and cultural creativity, and enriches the width and depth of career guidance.

Innovation and entrepreneurship are the strongest voices of the 21st century. The construction and development of vocational guidance courses should "jump out of the fixed framework" and actively consider the specific content of "employment increasing by entrepreneurship" in the curriculum development, give play to the role of vocational guidance of colleges and universities in the innovative national strategy, and face up to the position of the curriculum in the talent cultivation, aims at college students' innovation and entrepreneurship education goals, guide college students to understand the connotation of innovation and entrepreneurship, look at employment and the workplace from concept innovation and technological innovation to innovation and entrepreneurship based on their job, mobilize the innovative entrepreneurial thinking of teachers and students in course guidance, carry out innovation and entrepreneurship training in course study, 
and integrate the innovation and entrepreneurship education into the vocational guidance course of college students in combination with the students' majors, and conduct group training in a way of module, instruct students' innovation and entrepreneurship content and encourage them to explore their career path.

\subsection{To enhance curriculum practice}

In the practical guidance of the college students' vocational guidance curriculum system, the effect of practical guidance is improved through innovative thinking practice, professional practice and competition practice.

Innovative thinking practice can inspire the expansion of college students' innovative thinking in the vocational guidance course, mobilize the active innovation and entrepreneurial thinking habits of teachers and students, learn from the innovative theory of innovative engineers, and "break the inertia of thinking and develop good habits of positive thinking”, (2) transform the shackles of traditional inertial thinking, and implement the college students' innovation and entrepreneurship training program in the vocational guidance course. It is also possible to bring the frontiers of innovation and entrepreneurship of the society into the campus through school-enterprise cooperation, off-campus entrepreneurial tutors, and off-campus entrepreneurship hatchery, to inspire the growth of innovative and entrepreneurial thinking.

Professional practice can explore scientific research innovation, creative innovation, product innovation, marketing model innovation in career guidance course, make use of innovative thinking practice and support relevant incentive policies, and encourage teachers and students to carry out relevant innovation and entrepreneurship research practices in their own profession, and promote research output with innovative thinking, cultivate the sense of innovative thinking, foster entrepreneurship spirit, and lay the foundation for the career development of college students.

The competition practice takes the opportunity of "Challenge Cup", "Internet +", "Entrepreneurship Competition" and other college students' innovation and entrepreneurship competitions to better stimulate the enthusiasm of vocational guidance course learning and the motivation of innovation and entrepreneurship practice. Colleges and universities should organize various types of employment competitions, innovation and entrepreneurship competitions, and so on, mobilize teachers and students to participate in various competitions, expand participation and coverage, and improve the classified guidance of college students' innovation and entrepreneurship projects, improve the effectiveness of innovation and entrepreneurship education and the various abilities of students in practice to prepare for the employment of college students.

\subsection{To deepen the integration of industry and education}

Serving the society is one of the basic functions of colleges and universities. The purpose of innovation and entrepreneurship education in college students' career guidance is to cultivate a young generation that meets the needs of social innovation in the new era, adapts to social development, and can achieve innovation and entrepreneurship based on its own development, which is also the fundamental purpose of talent training in colleges and universities. In the vocational guidance, it is necessary to combine with the requirements of the connotative development and construction of colleges and universities, deepen the "integration of industry and education" and "cooperation between government, industry, education and research" in different disciplines, analyze the needs and evaluations of government, society and industry for college students' innovation and entrepreneurship, understand the pain points of college students' innovation and entrepreneurship, propose the guidance programs for college students' innovation and entrepreneurship that meet the needs of the society, create more channels for innovation and entrepreneurship practice outside the school, and strengthen the effectiveness of career guidance. Teachers are encouraged to work in enterprises to fill in the shortcomings of some teachers' lack of industry practice, and to improve the level of teachers in the field of career guidance such as innovation and entrepreneurship, to provide college students with the opportunity to practice in society, industry and enterprises, participate in the innovation and entrepreneurship competition, and build a practical platform for innovation and entrepreneurship training projects, so that the 
industry and enterprises can truly participate in the guidance of college students' innovation and entrepreneurship practice and actual combat, give full play to the advantages inside and outside the school, gather the wisdom of all parties, and combine vocational guidance to train the innovation and entrepreneurial spirit and professional ability of college students.

The $19^{\text {th }}$ CPC National Congress proposed that "Employment is the biggest people's livelihood. It is necessary to encourage the entrepreneurship to increase employment and promote multi-channel employment and entrepreneurship of college graduates." Vocational guidance course in colleges and universities, as compulsory course, shall continuously improve curriculum management, curriculum construction, teaching staff, practical guidance, industry-education integration of vocational guidance course, focus on connotative development of higher education, improve the quality of talent cultivation, inspire innovation and entrepreneurship potential of college students, train innovation and entrepreneurship capability, and enhance innovation and entrepreneurship level to provide effective vocational guidance for high-quality employment of college students.

\section{References}

[1] Editorial group. Chen Guojing. Innovation Vocational Guidance -New Concept [M]. China Labor and Social Security Press, 2016: 17.

[2] Liu Xuntao, Cao He, TRIZ Theory and Application [M]. Beijing University Press, 2015: 18.

[3] Qian Zongxia. A Discussion on the Role of Career Guidance in Promoting College Students' Employment [J]. Journal of Beijing City University, 2016, (1): 82.

[4] Wu GuanGwei. Analysis on New Model of Employment Guidance Course for College Students with the Core of Innovation and Entrepreneurship Education [J]. Data of Culture and Education, 2017, (23): 142.

[5] Su Tingmin. On the Role and Importance of Vocational Guidance in Promoting Employment of College Students [J]. New Campus, 2015, (3): 195-196.

[6] Zhao Hongjun. Research on Path of Employment Guidance Course of Higher Vocational Colleges under the Mass Innovation and Entrepreneurship -Taking Huainan Vocational Technical College as an Example [J]. Shaanxi Education, 2017, (3):69—70.

[7] Xie Xue. Analysis on Employment Guidance Model with the Core of Innovation and Entrepreneurship Capability [J]. Education and Vocation, 2017, (12):70—73. 